\title{
Analisis Kualitas Website Badan Pengembangan Sumber Daya Manusia Menggunakan Metode Webqual 4.0
}

\section{Website Quality Analysis of Human Resources Development Agency Using Webqual 4.0 Method}

\author{
Yanto Suharto \\ Badan Pengembangan Sumber Daya Manusia Provinsi DKI Jakarta, Widyaiswara \\ e-mail: yanwibpsdmdki@gmail.com \\ Eko Hariadi \\ Badan Pengembangan Sumber Daya Manusia Provinsi DKI Jakarta, Widyaiswara \\ e-mail: eko.hariadi@jakarta.go.id
}

\begin{abstract}
This study aims to determine the quality of the website of the DKI Jakarta Province Human Resources DevelopmentAgency with the address https://www.bpsdm.jakarta.go.id as a media of information about activities and institutionsrelated to the development of competencies for civil servants (PNS) within the Government. DKI Jakarta Province isbased on the perceptions of end users by analyzing end users' perceptions of usability, informaton quality and interaction quality using the WebQual 4.0 method. Data collection was carried out by survey using a questionnaire via Geogle Form with 22 statements based on the WebQual dimension and one statement about the whole (overall) with 438 respondents from the entire population of civil servants of the DKI Jakarta Provincial Government as manyas 60,691 people as of September 30, 2020, but who meet requirements as many as 398 respondents. The website quality analysis stage is by describing the survey data. The prerequisite for the test is to test the validity and reliability. Furthermore, data analysis by calculating the score and average on each indicator. The results of this test analysis indicate that the variables of usability, informaton quality and interaction quality on the website of the BPSDM DKI Jakarta Province have quality. The results of this study have implications for the need for BPSDM DKI Jakarta Province to evaluate the maintenance and development of the website that has been built used to improve service quality.
\end{abstract}

Keywords: analysis, quality, website, WebQual 4.0

\begin{abstract}
ABSTRAK
Penelitian ini bertujuan untuk mengetahui kualitas website Badan Pengembangan Sumbr Daya Manusia Provinsi DKI Jakarta dengan alamat https://www.bpsdm.jakarta.go.id sebagai media informasi tentang kegiatan dan kelembagaan terkait pengembangan kompetesi bagi pegawai negeri sipil (PNS) di lingkungan Pemerintah Provinsi DKI Jakarta berdasarkan persepsi pengguna akhir dengan menganalisis persepsi pengguna akhir terhadap usability, informaton quality dan interaction quality menggunakan metode WebQual 4.0. Pengumpulan data dilakukan dengan survey menggunakan kuesioner melalui Geogle Form dengan 22 pernyataan berdasarkan dimensi WebQual dan satu pernyataan tentang keseluruhan (overall) dengan responden sebanyak 438 orang dari populasi seluruh ASN PNS Pemerintah Provinsi DKI Jakarta sebanyak 60.691 orang per tanggal 30 September 2020, namun yang memenuhi syarat sebanyak 398 responden. Tahap analisis kualitas website dengan mendeskripsikan atau menggambarkan data hasil survey. Adapun prasyarat uji adalah dengan uji validitas, reliabilitas. Selanjutnya dilakukan analisis data dengan menghitung skor dan rata-rata setiap indikator. Hasil analisis pengujian ini menunjukkan bahwa variabel usability, informaton quality dan interaction quality website BPSDM Provinsi DKI Jakarta berkualitas. Hasil penelitian ini berimplikasi pada perlunya BPSDM Provinsi DKI Jakarta melakukan evaluasi terhadap pemeliharan dan pengembangan website yang telah dibangun digunakan untuk meningkatkan kualitas pelayanan.
\end{abstract}

Kata Kunci: analisis, kualitas, website, WebQual 4.0

\footnotetext{
*Corresponding author
} 


\section{PENDAHULUAN}

Revolusi industri 4.0 telah mendorong percepatan perkembangan teknologi informasi yang mendukung kegiatan dalam menyampaikan informasi baik komersial maupun nonkomersial. Kondisi pandemi Covid-19 saat ini semakin mendukung dan menuntut semua elemen masyarakat untuk memanfaatkan teknologi informasi dalam berbagai aspek kehidupan. Melalui kebijakan $E$ Government yang telah dirilis oleh pemerintah menjadi acuan bagi setiap lembaga pemberintah untuk membangun dan mengembangkan media berbasis teknologi informasi dalam bentuk website. Pemerintah telah merespon terkait e-Government tersebut dengan diterbitkannya Instruksi Presiden Nomor 3 Tahun 2003 tentang Kebijakan dan Strategi Nasional Pengembangan E-Government dan Keputusan Menteri Komunikasi dan Informasi Nomor 57 Tahun 2003 tentang Panduan Penyusunan Rencana Induk Pengembangan E- Government. Salah satu wujud nyata dari pengaplikasian e-government yang umumdilaksanakan dan diatur pelaksanaannya di Indonesia adalah pembuatan situs web pemerintah daerah.

Anttiroiko (2008) memaknai e-government sebagai pemanfaatan teknologi informasi dan komunikasi oleh pemerintah terutama aplikasi berbasis web dalam rangka untuk mendukung kerja pemerintah agar lebih responsif dan efisien dengan memfasilitasi fungsi administrasi dan manajerial. Permasalahannya pemanfaatan e-government tidak secara langsung mampu meningkatkan kualitas pelayanan publik oleh lembaga pemerintah yang bersangkutan dan hal ini harus menjadi perhatian dalam membangun aplikasi berbasis web. Karena banyak layanan $e$ government yang dibangun namun tidak dimanfaatkan, sebagaimana Chutimaskul et al., (2008) menyatakan bahwa banyak layanan e-government yang telah dikembangkan namun nampaknya tidak ada perhatian yang memadai terhadap aspek pengguna dan sejauh mana kualitas layanannya, sehingga pemerintah atau organisasi publik pada umumnya perlu memperhatikan dan mengontrol kualitas layanan e-government.

Badan Pengembangan Sumber Daya Manusia (BPSDM) Provinsi DKI Jakarta sebagai salah satu organisasi perangkat daerah telah membangun dan mengembangkan layanan egovernment berupa website dengan alamat https://www.bpsdm.jakarta.go.id yang bertujuan untuk memberikan informasi tentang kegiatan dan kelembagaan diklat kepada pegawai negeri sipil (PNS). Melalui website tersebut diharapkan dapat membantu Pegawai Negeri Sipil (PNS) selaku konsumen dari BPSDM Provinsi DKI Jakarta untuk mencari informasi mengenai kegiatan pengembangan kompetensi ataupun informasi kelembagaan dengan mudah dan cepat.Selain itu, dengan adanya website tersebut juga diharapkan dapat membantu kinerja pegawai BPSDM Provinsi DKI Jakarta dalam penyelenggaraan kewenangan di bidang pengembangan kompetensi.

Pentingnya penelitian ini karena sejauh ini pengelola belum pernah melakukan pengukuran kualitas website yang dibangun sehingga sulit mengetahui sejauh mana website memenuhi harapan pengguna dalam pelayanan publik terkait informasi kediklatan maupun organisasi. Kualitas website telah menjadi salah satu isu strategis dalam komunikasi dan transaksi dengan pelanggan/pengguna. WebQual merupakan salah satu metode pengukuran kualitas website yang dikembangkan oleh Barnes dan Vidgen dimana WebQual terdiri dari tiga dimensi yang mewakili kualitas dari website, yaitu dimensi kemudahan penggunaan (Usability Quality), dimensi kualitas informasi (Information Quality), dan kualitasinteraksi (Interaction Quality) (Tarigan, 2008). WebQual berdasarkan pada konsep Quality Fuction Deployment (QFD) yaitu suatu proses yang berdasarkan pada "voice of costumer" dalampengembangan dan implementasi suatu produk atau jasa. Dari konsep QFD tersebut, WebQualdisusun berdasarkan pada persepsi pengguna akhir (end user) terhadap suatu website.

Penelitian sebelumnya menunjukkan adanya hubungan yang sangat kuat antara variabel Usability, information quality dan service interaction quality terhadap overall impressiondengan hubungan yang searah. Hasil Penelitian ini memberikan kontribusi dalam menentukan dimensidimensi yang akan digunakan dalam penelitian ini. Sedangkan Penelitian Tarigan (2008) mengenai e-library dengan metode WebQual juga menyatakan bahwa suatu website akan sangat berpengaruh terhadap kepuasan pengguna apabila faktor-faktor yang terdapat pada WebQual atau kualitas website utamanya kualitas penggunaan memiliki kualitas yang baik. 
Hasil penelitian terhadap website provinsi Bengkulu menunjukkan bahwa responden setuju terhadap usability website, cukup berkualitas dan tidak setuju terhadap interaksi pelayanan. Penilaian terhadap website Bengkulu secara keseluruhan adalah cukup berkualitas (Diana, 2014). Demikian juga dengan penelitian tentang kualitas website BNPB menyimpulkan bahwa variabelvariabel Usability (kegunaan), Information Quality (kualitas informasi), dan Interaction Quality (kualitas interaksi) memberikan pengaruh positif terhadap User Satisfaction dengan persentase yang berbeda-beda (Rohman \& Kurniawan, 2017). Kedua penelitian ini dilakukan pada website institusi Pemerintah di daerah dan di pusat yang dapat dijadikan acuan dalam penggunaan metode webqual untuk melakukan penelitian kualitas website pada Satuan Kerja Pemerintah Daerah (SKPD) pada Pemerintah Provinsi DKI Jakarta.

Pertimbangan-pertimbangan seperti inilah yang mendorong penulis untuk melakukan sebuah penelitian terhadap website BPSDM Provinsi DKI untuk mengevaluasi sejauhmana kualitas website yang dimiliki sehingga dapat memberikan kepuasan kepada pengguna, karena sejak website ini diimplementasikan belum pernah dilakukan evaluasi mengenai kualitasnya. Hasil penelitian ini diharapkan dapat mengevaluasi kualitas website, sehingga mendapatkan umpan balik yang dapat dijadikan sebagai acuan untuk pengembangan dan perbaikan website.

\section{Tinjauan Pustaka}

Kualitas menurut Ishikawa dalam Budi \& Tyastianti (2019) adalah kepuasan pelanggan, sedangkan menurut Feigenbaum menyatakan kualitas adalah kepuasan pelanggan sepenuhnya (full customer satisfaction). Menurut Ariani (2004), konsep kualitas harus bersifat menyeluruh, baik produk maupun prosesnya. Kualitas produk meliputi kualitas bahan baku dan barang jadi, sedangkan kualitas proses meliputi segala sesuatu yang berhubungan dengan proses produksi perusahaan manufaktur dan proses penyediaan jasa atau pelayanan perusahaan jasa. Kualitas harus dibangun sejak awal, dari penerimaan input hingga perusahaan menghasilkan output bagi pelanggannya.

Sedangkan website menurut Yuhefizar \& Hidayat (2006) adalah keseluruhan halamanhalaman web yang terdapat dalam sebuah domain yang mengandung informasi. Sebuah website biasanya dibangun atas banyak web yang saling berhubungan. Menurut Simarmata (2010), web adalah sebuah sistem dengan informasi yang disajikan dalam bentuk teks, gambar, suara, dan lainnya yang tersimpan dalam sebuah server web internet yang disajikan dalam bentuk hypertext. Informasi web pada umumnya ditulis dalam format HTML. Interaksi web dibagi dalam 3 langkah yaitu permintaan, pemrosesan dan jawaban.

Kualitas website menurut Hyejeong dan Niehm dalam Puspitasari et al. (2013), para peneliti terdahulu membagi dimensi kualitas website menjadi lima yaitu: (1) informasi; (2) keamanan; (3) kemudahan; (4) kenyamanan; dan (5) kualitas pelayanan. Kualitas website dapat diukur dengan menggunakan metode WebQual yang sudah banyak digunakan dalam pengukuran website komersil. Menurut Slabey dalam Abbas (2013), WebQual adalah pengukuran bedasarkan quality function deployment (QFD). WebQual adalah suatu pengukuranuntuk mengukur kualitas dari sebuah website berdasarkan instrument-instrumen penelitian yang dapat dikategorikan kedalam tiga variabel yaitu: usability, information quality, dan services interaction. 
WebQual 4.0 disusun berdasarkan tiga dimensi, yaitu: usability, kualitas interaksi (information quality), dan interaksi layanan (service interaction), sebagaimana di ilustrasikan dalam gambar dibawah ini:

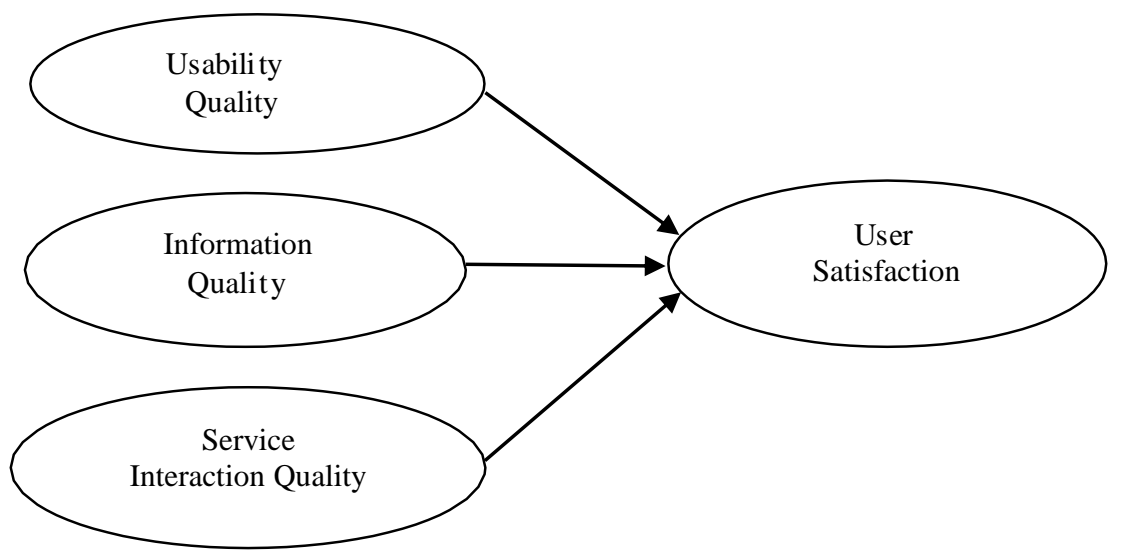

\section{Gambar 1. Model WebQual 4.0}

Sumber: Sanjaya (2012)

Persepsi penggguna tentang suatu sistem informasi yang baik adalah sebuah sistem dimana pengguna merasa puas dengan kualitas dari website. Kualitas ini termuat dalam tiga dimensi dari WebQual versi 4.0. Penelitian sebelumnya menyarankan bahwa dimensi WebQual dapat memprediksi kepuasan pengguna dan maksud pengguna dalam mengunakan kembali website (Sanjaya, 2012).

Metode WebQual sebagai model pengukuran kualitas website, dengan kuesionernya berdasarkan 3 dimensi dapat dilihat pada tabel di bawah ini.

Tabel 1. WebQual 4.0 Instrument Menurut Barnes dan Vidgen (2000)

\begin{tabular}{ll}
\hline Category & WebQual Questions \\
\hline Usabality & I find the site easy to learn to operate \\
2. & My interaction with the site is clear and understandable \\
3. & I find the site easy to navigate \\
4. & I find the site easy to use \\
5. & The site has an attractive appearance \\
6. & The design is appropriate to the type of site \\
7. & The site conveys a sense of competency \\
8. The site creates a positive experience for me & 9. Provides accurate information \\
10. Provides believable information \\
11. Provides timely information \\
12. Provides relevant information \\
13. Provides easy to understand information \\
14. Provides information at the right level of detai \\
15. I Present the information in appropriate format \\
16. Has a good reputation \\
17. It feels safe to complete transaction \\
18. My personal information feels secure \\
19. Creates a sense of personalization \\
20. Convey a sense of community \\
21. Make it easy to communicate with the organization \\
22. I feel confident that goods/services will be delivered as
\end{tabular}

1. I find the site easy to learn to operate

2. My interaction with the site is clear and understandable

4. I find the site easy to use

5. The site has an attractive appearance

6. The design is appropriate to the type of site

9. Provides accurate information

0. Provides believable information

ides timely information

14. Provides information at the right level of deta

15. 1 Present the information in appropriate format

16. Has a good reputation

20. Convey a sense of community

21. Make it easy to communicate with the organization

promised 


\section{METODE PENELITIAN}

Penelitian ini menggunakan metode deskriptif kuantitatif. Penelitian deskriptif yaitu penelitian yang berguna untuk memberikan suatu deskripsi terhadap suatu fenomena sosial/alam secara sistematis, faktual dan aktual. Menurut Sugiyono (2013) penelitian ini dikategorikan sebagai metode kuantitatif karena data penelitian berupa angka-angka dan analisis dengan menggunakan metode statistik.

Variabel-variabel yang digunakan pada penelitian ini merujuk pada metode WebQualversi 4.0 berdasarkan penelitian yang dilakukan oleh Barnes dan Vidgen yaitu Dimensi kualitaswebsite terdiri dari usability, information, dan service interaction digunakan sebagai variabel bebas (Independent), sedangkan kualitas Web sebagai variabel terikat (dependent).

Penelitian ini menggunakan populasi dan sampel sebagai subyek, dimana populasi adalah wilayah generasi yang terdiri dari obyek/subyek yang memiliki kualitas dan karakteristik tertentu yang ditetapkan oleh peneliti yang digunakan untuk dipelajari lalu dibuat kesimpulan (Sugiyono, 2017). Populasi yang diambil pada penelitian ini yaitu seluruh Aparatur Sipil Negara PNS di lingkungan Pemerintah Provinsi DKI Jakarta berjumlah 60.691 orang per 30 September 2020 berdasarkan data Badan Kepegawaian Daerah (BKD) (BKD DKI Jakarta, 2020).

Sedangkan sampel adalah bagian dari jumlah dan karakteristik yang dipunyai oleh populasi tersebut. Sampel pada penelitian ini adalah sebagian pengguna yang telah melakukan berbagai transaksi pada pada website http://bpsdm.jakarta.go.id dijadikan sebagai responden untukmengisi kuesioner yang disebar oleh penulis. Besar sampel minimal menggunakan rumus Slovinsebagai berikut:

$$
\mathrm{n}=\frac{N}{1+N(e)^{2}}
$$

Keterangan:

$\mathrm{N}=$ Ukuran sampel/jumlah responden

$\mathrm{N}=$ Ukuran populasi

$\mathrm{E}=$ Presentase kelonggaran ketelitian kesalahan pengambilan sampel yang masihbisa ditolerir; $\mathrm{e}=0,05(5 \%)$

Jumlah populasi dalam penelitian ini adalah sebanyak 60.691 orang, presentase kelonggaran yang digunakan adalah 5\% dan hasil perhitungan dapat dibulatkan untuk mencapai kesesuaian, maka untuk mengetahui sampel penelitian, dengan perhitungan sebagai berikut:

60.691

$$
\begin{aligned}
N & =\frac{}{1+60.691 \text { orang }\left(0,05^{2}\right)} \\
& =397,3 \approx 398 \text { orang }
\end{aligned}
$$

Dengan demikian besar sampel minimal dalam penelitian ini sebanyak 398 orang. Teknik pengambilan sampel menggunakan sampel incidental dengan teknik nonprobability sampling yaitu teknik penentuan sampel berdasarkan kebetulan yaitu siapa saja yang secara kebetulan bertemu dengan peneliti dan dapat digunakan sebagai sampel bila dipandang orang kebetulan ditemui itu cocok sebagai sumber data (Sugiyono, 2010)

\section{Teknik Pengumpulan Data}

Pengumpulan data pada penelitian ini menggunakan beberapa teknik, yaitu: 1) Kuesioner (Angket), yaitu teknik pengumpulan data yang dilakukan dengan cara memberi seperangkat pertanyaan atau pernyataan tertulis kepada responden untuk dijawabnya. Kuesioner merupakan teknik pengumpulan data yang efisien bila peneliti tahu dengan pasti variabel yang akan diukur dan tahu apa yang bisa diharapkan dari responden (Sugiyono, 2015). Studi dokumen, yaitu teknik pengumpulan data yang menggunakan dokumen sebagai sumber penelitian. Guba dan Lincoln mendefinisikan dokumen sebagai berikut: dokumen adalah setiap bahan tertulis ataupunfilm, yang dipersiapkan karena adanya permintaan seorang penyidik (Sitorus, 2011). Studi dokumentasi 
yaitu mengadakan pengujian terhadap dokumen yang dianggap mendukung hasil penelitian. Analisis dokumen dilakukan untuk mengumpulkan data yang bersumber dari arsip dan dokumen penyelenggara diklat.

Instrumen yang digunakan dalam kuesioner yaitu: lembar kuesioner (angket) dan alat tulis. Jenis pertanyaan yang digunakan dalam kuesioner penelitian ini adalah berupa pertanyaantertutup (close ended question). Dalam penelitian ini, skala likert 1-6 digunakan sebagai tingkat pengukuran yaitu yaitu Sangat Setuju (SS), Setuju (S), Agak Setuju (AS), Kurang Setuju (KS), Tidak Setuju (TS), dan Sangat Tidak Setuju (STS). Penggunaan 6 point skala Likert cocok untuk penelitian dengan banyak variabel karena menghindari jawaban netral dan dapat mengurangi penyimpangan atau resiko penyimpangan pengambilan keputusan pribadi dan memiliki kehandalan tinggi (Chomeya, 2010). Jawaban pertanyaan menggunakan Skala Likert dengan enam. Adapun alat yang digunakan adalah angket dengan Geogle Form yang merupakan salah satu aplikasi Fomulir online yang disediakan oleh Google secara cuma-cuma dan realtime.

\section{Uji Validitas Instrumen}

Sugiyono (2013) berpendapat "Valid berarti instrumen tersebut dapat digunakan untuk mengukur apa yang seharusnya diukur". Suatu instrumen penelitian dikatakan valid apabila mampu mengukur dan mengungkap data dari variabel yang diteliti secara tepat. Instrumen penelitian harus memiliki validitas internal dan eksternal, yaitu sebagai berikut:

1) Validitas Internal

Validitas internal terdiri dari validitas kontruksi dan validitas isi. Menurut Sugiyono (2013) untuk instrumen nontest yang digunakan untuk mengukur sikap cukup memenuhi validitas konstruksi. Validitas internal dalam instrumen penelitian ini diuji dengan pengujian konstruksi dari penilai ahli.

2) Validitas Eksternal

Sugiyono (2013) berpendapat bahwa "validitas eksternal dari suatu instrumen dikembangkan berdasarkan fakta empiris". Instrumen diuji dengan cara membandingkan antara kriteria yang ada pada instrumen dengan fakta-fakta empiris yang terjadi di lapangan. Menurut Djamaludin Ancok (Singarimbun \& Effendi, 2019) sangat disarankan agar jumlah respondenuntuk uji coba minimal 30 responden. Dengan jumlah ini, maka distribusi skor (nilai) akanlebih mendekati kurva normal. Asumsi kurva normal sangat diperlukan dalam perhitunganstatistik.

Dalam penelitian ini, perhitungan hasil uji coba menggunakan analisis Cronbach Alpha pada Statistical Product and Serice Solution (SPSS) versi 16.0 for Windows. Untuk mengetahui validitas kuesioner dilakukan dengan membandingkan nilai $r_{\text {hitung }}$ dengan nilai $r_{\text {tabel }}$ pada taraf kepercayaan 5 persen dan $\mathrm{df}=\mathrm{n}-2=28$, bila $\mathrm{r}_{\text {hitung }}>\mathrm{r}_{\text {tabel }}$, maka pernyataan tersebut valid.

Tabel 2. Hasil Uji Validitas Eksternal

\begin{tabular}{lccc}
\hline No. Item & r $_{\text {hitung }}$ & $\mathrm{r}_{\text {tabel }}$ & Keterangan \\
\hline Variabel Usability & & & Valid \\
WEB-U1 & 0,842 & 0,3610 & Valid \\
WEB-U2 & 0,875 & 0,3610 & Valid \\
WEB-U3 & 0,812 & 0,3610 & Valid \\
WEB-U4 & 0,802 & 0,3610 & Valid \\
WEB-U5 & 0,789 & 0,3610 & Valid \\
WEB-U6 & 0,581 & 0,3610 & Valid \\
WEB-U7 & 0,827 & 0,3610 & Valid \\
WEB-U8 & 0,873 & 0,3610 & \\
\hline Variabel Information Quality & & & Valid \\
WEB-IQ1 & 0,764 & 0,3610 & Valid \\
WEB-IQ2 & 0,869 & 0,3610 & Valid \\
WEB-IQ3 & 0,859 & 0,3610 & Valid \\
WEB-IQ4 & 0,812 & 0,3610 & Valid \\
WEB-IQ5 & 0,3610 & Valid \\
WEB-IQ6 & 0,869 & 0,3610 & Valid \\
WEB-IQ7 & 0,612 & 0,3610 & \\
\hline
\end{tabular}




\begin{tabular}{llll}
\hline No. Item & rhitung & rtabel & Keterangan \\
\hline Variabel Interaction Quality & & & \\
\hline WEB-SQ1 & 0,914 & 0,3610 & Valid \\
WEB-SQ1 & 0,850 & 0,3610 & Valid \\
WEB-SQ1 & 0,547 & 0,3610 & Valid \\
WEB-SQ1 & 0,765 & 0,3610 & Valid \\
WEB-SQ1 & 0,827 & 0,3610 & Valid \\
WEB-SQ1 & 0,860 & 0,3610 & Valid \\
\hline
\end{tabular}

Seluruh intem pernyataan WebQual 4.0 untuk mengukur kualitas website hattps://www.bpsdm.jakarta.go.id dinyatakan valid.

\section{Uji Reliabilitas}

Reliabilitas instrumen penelitian menunjukkan bahwa suatu instrumen layak dipercaya untuk dipakai sebagai alat pengumpul data. Uji realibilitas instrumen digunakan rumus Cronbach Alpha (Arikunto, 2010):

$$
\mathrm{C} \sigma=\left(\frac{k}{k-1}\right)\left(1-\frac{\sum \sigma b^{2}}{\sigma_{t}^{2}}\right)
$$

Keterangan:

$$
\begin{array}{ll}
\mathrm{C} \sigma & =\text { Reliabilitas instrumen } \\
\mathrm{k} & =\text { Banyaknya butir pertanyaan } \\
\sum_{2} \sigma \mathrm{b}^{2} & =\text { Jumlah varians butir } \\
\sigma \mathrm{t} & =\text { Varians total }
\end{array}
$$

Untuk mencari tiap butir menggunakan rumus varians sebagai berikut:

$$
\sigma_{t}^{2}=\frac{\sum x^{2}-\frac{\left(\sum x\right)^{2}}{n}}{n}
$$

Keterangan:

$$
\begin{array}{ll}
\sigma^{2} \mathrm{t} & =\text { Harga varians total } \\
\sum_{\mathrm{n}} \mathrm{x}^{2} & =\text { Jumlah kuadrat skor total } \\
& =\text { Jumlah kuadrat dari jumlah skor total } \\
& =\text { Jumlah responden }
\end{array}
$$

Untuk mengetahui reliabilitas instrumen dilakukan dengan membandingkan nilai rAlpha Cronbach dengan nilai rtabel pada taraf kepercayaan 5 persen dan $\mathrm{df}=\mathrm{n}-2=28$, bila rhitung > rtabel, maka pernyataan tersebut reliabel. Perhitungan reliabilitas dengan rumus Cronbach Alpha menggunakan bantuan program IBM SPSS 16.0 for windows.

Tabel 3. Hasil Uji Reliabilitas Instrumen

\begin{tabular}{lccc}
\hline Variabel & $\begin{array}{c}\text { rAlpha } \\
\text { Cronbach }\end{array}$ & rtabel & Keterangan \\
\hline Usability (WEB-U) & 0,944 & 0,3610 & Reliabel \\
\hline Information Quality (WEB-IQ) & 0,929 & 0,3610 & Reliabel \\
\hline Interaction Quality (WEB-SQ) & 0,925 & 0,3610 & Reliabel \\
\hline
\end{tabular}

Hasil perhitungan pengujian reliabilitas dilihat bahwa nilai Cronbach Alpha dari usability (X1) sebesar 0,944, information quality (X2) sebesar 0,929, dan interaction quality (X3) sebesar 0,925 sehingga dapat disimpulkan bahwa hasil pengujian relibilitas dinyatakan reliabel.

\section{Teknik Analisis Data}

Analisis deskriptif menurut Sugiyono (2013) merupakan statistik yang digunakan untuk menganalisa data dengan cara mendeskripsikan atau menggambarkan data yang telah terkumpul sebagaimana adanya tanpa bermaksud membuat kesimpulan yang berlaku untuk umum atau generalisasi. Tujuannya untuk merangkum sekumpulan data kedalam bentuk yang mudah dibaca dan cepat memberikan informasi. Pendekatan deskriptif ini digunakan untuk memperjelas atau menggambarkan fakta yang terjadi pada variabel yang diteliti yaitu kegunaan (Usability), kualitas

Jurnal Manajemen dan Organisasi

( Vol. 12 No. 2 Hal. 109-121 
informasi (Information Quality), dan kualitas interaksi pelayanan (Service Interaction Quality), maupun secara keseluruhan (Overall).

Adapun langkah-langkah analisis deskriptif yang dilakukan dalam penelitian ini adalah sebagai berikut:

1. Menghitung score pada setiap indikator variabel

Berikut adalah rumus penilaian nilai skor pada setiap indikator dalam variable:

Perhitungan Skor setiap indikator: $\mathbf{F}$ x S

Dimana:

$\mathrm{F}=$ Frekuensi pemilih

$\mathrm{S}=$ Skor pada skala jawaban

2. Menghitung rentang skala untuk mendapatkan analisa deskriptif.

Analisa deskriptif adalah metode yang berfungsi untuk mendeskripsikan atau memberi gambaran terhadap obyek Analisa ini dilakukan dengan cara menggunakan rumus rentang skala (Sugiyono, 2013) sebagai berikut:

Rentang Skala $(\mathrm{RS})=($ score terbesar - score terkecil $) /$ jumlah interval

Rentang Skala $(\mathrm{RS})=$ score terbesar-score terkecil

$$
\begin{array}{cl}
6-1 & \text { Jumlah interval } \\
---8,86 & =
\end{array}
$$

Dengan demikian jarak antar jenjang untuk masing-masing kategori adalah 0,8 sehingga kategorinya adalah sebagai berikut:

Tabel 4. Rentang Skala Kualitas Website BPSDM Provinsi DKI Jakarta

\begin{tabular}{ll}
\hline Rentang Skala & Kriteria \\
\hline $1,00-1,80$ & Sangat Tidak Berkualitas \\
$1,81-2,64$ & Tidak Berkualitas \\
$2,65-3,48$ & Kurang Berkualitas \\
$3,49-4,32$ & Agak Berkualitas \\
$4,33-5,16$ & Berkualitas \\
$5,17-6,00$ & Sangat Berkualitas \\
\hline
\end{tabular}

3. Menghitung rata-rata pada setiap indikator pada setiap variabel.

Hal ini dilakukan agar dapat menarik kesimpulan indikator-indikator yang akan dilakukan oleh BPSDM Provinsi DKI Jakarta. Berikut adalah rumus rata-rata dalam setiap indikator dalam variabel:

$$
\begin{aligned}
& \quad(F \times S) \\
& \text { Rata-rata }=\text {-------- } \\
& \text { Dimana: } \\
& \text { S = Skor pada skala jawaban } \\
& \mathrm{F}=\text { Frekuensi pemilih } \\
& \mathrm{n}=\text { Jumlah responden }
\end{aligned}
$$




\section{HASIL DAN PEMBAHASAN}

\section{Hasil}

\section{Karakteristik Responden}

Tabel 5. Karakteristik Responden

\begin{tabular}{clll}
\hline Karakteristik Responden & $\mathrm{f}$ & $\%$ \\
\hline Umur & & & \\
- & $18-25$ th & 35 & 8,79 \\
- & $26-30$ th & 137 & 34,42 \\
- & $31-35$ th & 62 & 15,58 \\
- & $36-40$ th & 18 & 4,52 \\
- & $41-45$ th & 10 & 2,51 \\
- & $46-50$ th & 37 & 9,30 \\
- & $51-55$ th & 60 & 15,08 \\
- & $50-60$ th & 39 & 9,80 \\
\hline Jumlah & & 398 & 100,0 \\
\hline Lama menggunakan Internet Tiap Hari & & \\
- & $\quad 2$ jam & 8 & 2,01 \\
- & $2-3$ jam & 34 & 8,54 \\
- & $3-5$ jam & 75 & 18,84 \\
- & $>5$ jam & 281 & 70,60 \\
\hline Jumlah & & 398 & 100,0 \\
\hline Frekuensi mengunjungi website bpsdm.jakarta.go.id & \multicolumn{2}{c}{} \\
$-\quad$ Kadang-kadang & 369 & 92,71 \\
- & Sering & 29 & 7,29 \\
\hline Jumlah & & 398 & 100,0 \\
\hline
\end{tabular}

Karakteristik responden berdasarkan usia responden dibagi delapan kelompok mengacu pada Badan Kepegawaian Negara (2020) menunjukkan bahwa kelompok usia 26-30 tahun terbanyak mengakses website bpsdm.jakarta.go.id. disusul kelompok usia 31-35 tahun (15,58 persen)dan kelompok usia 51-55 tahun (15,08 persen).

Karakteristik responden berdasarkan Lama menggunakan Internet Tiap Hari menunjukan bahwa responden yang menggunakan internet tiap hari $>5$ jam terbanyak $(70,60$ persen), disusul responden yang menggunakan internet tiap hari 3-5 jam (18,84 persen).

Karakteristik responden berdasarkan frekuensi mengunjungi website bpsdm.jakarta.go.id. menunjukan bahwa responden dengan frekuensi mengunjungi website kadang-kadang paling banyak (92,71 persen) dibandingkan responden dengan frekuensi mengunjungi website sering $(7,29$ persen $)$.

\section{Analisis Deskriptif}

a. Kualitas Website BPSDM Provinsi DKI Jakarta Berdasarkan Indikator Variabel Kegunaan (Usability)

Tabel 6. Kualitas Website BPSDM Provinsi DKI Jakarta Berdasarkan Indikator Variabel Kegunaan (Usability)

\begin{tabular}{|c|c|c|c|c|c|c|c|c|c|}
\hline \multirow{2}{*}{$\begin{array}{l}\text { Variabel yang } \\
\text { Diukur }\end{array}$} & \multicolumn{2}{|c|}{ Skor Jawaban } & \multirow[b]{2}{*}{$\mathrm{AM}$} & \multirow[b]{2}{*}{$\mathrm{KM}$} & \multirow[b]{2}{*}{$\mathrm{TM}$} & \multirow[b]{2}{*}{ STM } & \multirow{2}{*}{$\begin{array}{l}\text { Total } \\
\text { Skor }\end{array}$} & \multirow{2}{*}{$\begin{array}{l}\text { Skor } \\
\text { Rata- } \\
\text { rata }\end{array}$} & \multirow[b]{2}{*}{ Interpretasi } \\
\hline & SM & M & & & & & & & \\
\hline $\begin{array}{l}\text { Mudah untuk } \\
\text { dioperasikan }\end{array}$ & 618 & 1115 & 232 & 27 & 10 & - & 2002 & 5,03 & Berkualitas \\
\hline $\begin{array}{l}\text { Interaksi dengan } \\
\text { website jelas dan } \\
\text { dapat dimengerti }\end{array}$ & 588 & 1110 & 272 & 21 & 10 & - & 1991 & 5,00 & Berkualitas \\
\hline $\begin{array}{l}\text { Mudah untuk } \\
\text { navigasi } \\
\text { (menampilkan antar } \\
\text { halaman) }\end{array}$ & 600 & 1050 & 288 & 33 & 10 & - & 1981 & 4,98 & Berkualitas \\
\hline $\begin{array}{l}\text { Menyajikan } \\
\text { tampilan yang } \\
\text { atraktif }\end{array}$ & 474 & 990 & 376 & 63 & 8 & 2 & 1913 & 4,81 & Berkualitas \\
\hline
\end{tabular}




\begin{tabular}{|c|c|c|c|c|c|c|c|c|c|}
\hline \multirow{2}{*}{$\begin{array}{l}\text { Variabel yang } \\
\text { Diukur }\end{array}$} & \multicolumn{2}{|c|}{ Skor Jawaban } & \multirow[b]{2}{*}{$\mathrm{AM}$} & \multirow[b]{2}{*}{$\mathrm{KM}$} & \multirow[b]{2}{*}{$\mathrm{TM}$} & \multirow[b]{2}{*}{ STM } & \multirow{2}{*}{$\begin{array}{l}\text { Total } \\
\text { Skor }\end{array}$} & \multirow{2}{*}{$\begin{array}{l}\text { Skor } \\
\text { Rata- } \\
\text { rata }\end{array}$} & \multirow[b]{2}{*}{ Interpretasi } \\
\hline & SM & M & & & & & & & \\
\hline $\begin{array}{l}\text { Tampilan sesuai } \\
\text { dengan jenis } \\
\text { website }\end{array}$ & 714 & 1045 & 240 & 18 & 6 & 1 & 2024 & 5,09 & Berkualitas \\
\hline $\begin{array}{l}\text { Adanya tambahan } \\
\text { pengetahuan dari } \\
\text { informasi website }\end{array}$ & 852 & 985 & 204 & 21 & 0 & 1 & 2063 & 5,18 & Berkualitas \\
\hline $\begin{array}{l}\text { Tepat dalam } \\
\text { penyusunan tataletak } \\
\text { informasi }\end{array}$ & 528 & 1060 & 320 & 27 & 10 & 4 & 1949 & 4,99 & Berkualitas \\
\hline $\begin{array}{l}\text { Mudah untuk } \\
\text { menemukan } \\
\text { alamat website }\end{array}$ & 822 & 950 & 220 & 36 & 2 & 3 & 2033 & 5,11 & Berkualitas \\
\hline Total & 5196 & 8305 & 2152 & 246 & 56 & 11 & 15596 & 5,03 & Berkualitas \\
\hline
\end{tabular}

Berdasarkan Tabel 6 di atas, ternyata skor yang paling tinggi adalah adanya tambahan pengetahuan dari informasi website dengan skor 2063, sedangkan skor terendah adalah menyajikan tampilan yang atraktif dengan skor 1913. Kegunaan (Usability) menghasilkan skor rata-rata 5,03. Apabila melihat tabel rentang skala ternyata Kegunaan (Usability) ini termasuk pada range 4,33 - 5,16, sehingga Kegunaan (Usability) pada website BPSDM Provinsi DKI Jakarta sudah berkualitas.

b. Kualitas Website BPSDM Provinsi DKI Jakarta Berdasarkan Indikator Variabel Kualitas Informasi (Information Quality)

Tabel 7. Kualitas Website BPSDM Provinsi DKI Jakarta Berdasarkan Indikator Variabel Kualitas Informasi (Information Quality)

\begin{tabular}{|c|c|c|c|c|c|c|c|c|c|}
\hline \multirow{2}{*}{ Variabel yangDiukur } & \multicolumn{2}{|c|}{ Skor Jawaban } & \multirow[b]{2}{*}{$\mathrm{AM}$} & \multirow[b]{2}{*}{ KM } & \multirow[b]{2}{*}{ TM } & \multirow[b]{2}{*}{ STM } & \multirow{2}{*}{$\begin{array}{l}\text { Total } \\
\text { Skor }\end{array}$} & \multirow{2}{*}{$\begin{array}{l}\text { Skor } \\
\text { Rata- } \\
\text { rata }\end{array}$} & \multirow[b]{2}{*}{ Interpretasi } \\
\hline & SM & M & & & & & & & \\
\hline $\begin{array}{l}\text { Menyediakan } \\
\text { informasi yang } \\
\text { dapat dipercaya }\end{array}$ & 1062 & 895 & 156 & 6 & 2 & - & 2121 & 5,33 & Berkualitas \\
\hline $\begin{array}{l}\text { Menyediakan } \\
\text { informasi yangup- } \\
\text { to-date }\end{array}$ & 792 & 965 & 256 & 21 & 4 & - & 2038 & 5,12 & Berkualitas \\
\hline $\begin{array}{l}\text { Menyediakan } \\
\text { informasi yang } \\
\text { mudah dibacadan } \\
\text { dipahami }\end{array}$ & 798 & 1010 & 236 & 3 & 6 & - & 2053 & 5,16 & Berkualitas \\
\hline $\begin{array}{l}\text { Menyediakan } \\
\text { informasi yang } \\
\text { cukup detail }\end{array}$ & 624 & 1050 & 292 & 27 & 2 & 1 & 1996 & 5,02 & Berkualitas \\
\hline $\begin{array}{l}\text { Menyediakan } \\
\text { informasi yang } \\
\text { relevan }\end{array}$ & 780 & 1075 & 196 & 9 & - & 1 & 2061 & 5,18 & Berkualitas \\
\hline $\begin{array}{l}\text { Menyediakan } \\
\text { informasi yang } \\
\text { akurat }\end{array}$ & 924 & 955 & 180 & 18 & 0 & 2 & 2079 & 5,22 & Berkualitas \\
\hline $\begin{array}{l}\text { Menyajikan } \\
\text { informasi dalam } \\
\text { format yang sesuai }\end{array}$ & 684 & 1080 & 244 & 12 & 6 & - & 2026 & 5,09 & Berkualitas \\
\hline Total & 5664 & 7030 & 1560 & 96 & 20 & 4 & 14374 & 5,12 & Berkualitas \\
\hline
\end{tabular}

Jurnal Manajemen dan Organisasi

(JMO), 12 No. 2

Agustus 2021 ,

Berdasarkan Tabel 7 di atas, ternyata skor yang paling tinggi adalah menyediakan informasi yang dapat dipercaya dengan skor 2021, sedangkan skor terendah adalah Menyediakan informasi yang cukup detail dengan skor 1996. Kualitas Informasi (Information Quality) menghasilkan skor rata-rata 5,12. Apabila melihat tabel rentang skala ternyata Kualitas Informasi (Information Quality) ini termasuk pada range 4,33 - 5,16, sehingga 
Kualitas Informasi (Information Quality) pada website BPSDM Provinsi DKI Jakarta sudah berkualitas.

c. Kualitas Website BPSDM Provinsi DKI Jakarta Berdasarkan Indikator VariabelKualitas Interaksi Pelayanan (Service Interaction Quality)

Tabel 8. Kualitas Website BPSDM Provinsi DKI Jakarta Berdasarkan IndikatorVariabel Kualitas Interaksi Pelayanan (Service Interaction Quality)

\begin{tabular}{|c|c|c|c|c|c|c|c|c|c|}
\hline \multirow[b]{2}{*}{ Variabel yang Diukur } & \multirow[b]{2}{*}{ SM } & \multirow[b]{2}{*}{ M } & \multicolumn{2}{|c|}{ Skor Jawaban } & \multirow[b]{2}{*}{$\mathrm{TM}$} & \multirow[b]{2}{*}{ STM } & \multirow{2}{*}{$\begin{array}{l}\text { Total } \\
\text { Skor }\end{array}$} & \multirow{2}{*}{$\begin{array}{l}\text { Skor } \\
\text { Rata- } \\
\text { rata }\end{array}$} & \multirow[b]{2}{*}{$\begin{array}{l}\text { Interpreta } \\
\text { si }\end{array}$} \\
\hline & & & $\mathrm{AM}$ & KM & & & & & \\
\hline $\begin{array}{l}\text { Situs memiliki } \\
\text { reputasi yang baik }\end{array}$ & 756 & 1065 & 208 & 21 & - & - & 2050 & 5,15 & Berkualitas \\
\hline $\begin{array}{l}\text { Menyediakan keamanan } \\
\text { untuk melengkapi transaksi } \\
\text { / interaksi }\end{array}$ & 612 & 1090 & 264 & 33 & 2 & - & 2001 & 5,03 & Berkualitas \\
\hline $\begin{array}{l}\text { Memberikan rasa aman } \\
\text { dalam } \\
\text { menyampaikan data } \\
\text { pribadi }\end{array}$ & 762 & 985 & 272 & 12 & 2 & 1 & 2034 & 5,11 & Berkualitas \\
\hline $\begin{array}{l}\text { Ada suasana komunitas } \\
\text { dengan tersedianya link } \\
\text { SKPD untuk kemudahan } \\
\text { komunikasi dengan } \\
\text { organisasi }\end{array}$ & 636 & 1020 & 284 & 39 & 6 & 1 & 1986 & 4,99 & Berkualitas \\
\hline $\begin{array}{l}\text { Mudah menarik } \\
\text { minat dan perhatian }\end{array}$ & 552 & 995 & 340 & 45 & 10 & 2 & 1944 & 4,88 & Berkualitas \\
\hline $\begin{array}{l}\text { Memberikan kemudahan } \\
\text { komunikasi dalam } \\
\text { merespon pertanyaan }\end{array}$ & 546 & 1065 & 308 & 36 & 8 & 1 & 1964 & 4,94 & Berkualitas \\
\hline
\end{tabular}

$\begin{array}{lllllllll}3864 & 6220 & 1676 & 186 & 28 & 5 & 11979 & 5,02 & \text { Berkualitas }\end{array}$

Berdasarkan Tabel 8 di atas, ternyata skor yang paling tinggi adalah situs memiliki reputasi yang baik dengan skor 2050, sedangkan skor terendah adalah mudah menarik minat danperhatian dengan skor 1944. Kualitas Interaksi Pelayanan (Service Interaction Quality) menghasilkan skor rata-rata 5,02. Apabila melihat tabel rentang skala ternyata Kualitas InteraksiPelayanan (Service Interaction Quality) ini termasuk pada range 4,33 - 5,16, sehingga KualitasInteraksi Pelayanan (Service Interaction Quality) pada website BPSDM Provinsi DKI Jakarta sudah berkualitas.

d. Kualitas Website BPSDM Provinsi DKI Jakarta Berdasarkan Indikator Variabel Keseluruhan (Interaction Quality)

Tabel 9. Kualitas Website BPSDM Provinsi DKI Jakarta Berdasarkan Indikator Variabel Keseluruhan (Overall)

\begin{tabular}{|c|c|c|c|c|c|c|c|c|c|c|}
\hline \multirow{2}{*}{ Variabel } & \multirow{2}{*}{ yangDiukur } & \multirow[b]{2}{*}{ SM } & \multirow[b]{2}{*}{ M } & \multicolumn{2}{|c|}{ Skor Jawaban } & \multirow[b]{2}{*}{$\mathrm{TM}$} & \multirow[b]{2}{*}{ STM } & \multirow{2}{*}{$\begin{array}{l}\text { Total } \\
\text { Skor }\end{array}$} & \multirow{2}{*}{$\begin{array}{l}\text { Skor } \\
\text { Rata } \\
\text {-rata }\end{array}$} & \multirow[b]{2}{*}{ Interpretasi } \\
\hline & & & & $\mathrm{AM}$ & KM & & & & & \\
\hline \multicolumn{2}{|c|}{$\begin{array}{l}\text { Tampilan situs secara } \\
\text { keseluruhan baik }\end{array}$} & 708 & 1115 & 184 & 21 & 4 & 2 & 2034 & 5,11 & Berkualitas \\
\hline \multicolumn{2}{|l|}{ Total } & 708 & 1115 & 184 & 21 & 4 & 2 & 2034 & 5,11 & Berkualitas \\
\hline
\end{tabular}

Berdasarkan Tabel 9 di atas, ternyata Tampilan situs secara keseluruhan baik mencapai skor 2034. Keseluruhan (Overall) menghasilkan skor rata-rata 5,11. Apabila melihat tabel rentang skala ternyata Keseluruhan (Overall) ini termasuk pada range 4,33 - 5,16, sehingga Keseluruhan (Overall) pada website BPSDM Provinsi DKI Jakarta sudah berkualitas. 
e. Skor Rata-rata Kualitas Website BPSDM Provinsi DKI Jakarta Berdasarkan Indikator Variabel Kegunaan (Usability), Kualitas Informasi (Information Quality), Kualitas Interaksi Pelayanan (Service Interaction Quality) dan Keseluruhan (Overall)

Tabel 10. Skor Rata-rata Kualitas Website BPSDM Provinsi DKI Jakarta Berdasarkan Indikator VariabelKegunaan (Usability), Kualitas Informasi (Information Quality), Kualitas Interaksi Pelayanan (Service Interaction Quality) dan Keseluruhan (Overall)

\begin{tabular}{llcl}
\hline Variabel yang Diukur & Total Skor & $\begin{array}{c}\text { Skor } \\
\text { Rata-rata }\end{array}$ & Interpretasi \\
\hline Kegunaan (Usability) & & 5,03 & Berkualitas \\
$\begin{array}{l}\text { Kualitas Informasi (Information Quality) } \\
\text { Kualitas Interaksi Pelayanan (Service }\end{array}$ & 15596 & 5,12 & Berkualitas \\
$\begin{array}{l}\text { Interaction Quality) } \\
\text { Keseluruhan (Overall) }\end{array}$ & 11979 & 5,02 & Berkualitas \\
\hline Total & 2034 & 5,11 & Berkualitas \\
\hline
\end{tabular}

Berdasarkan Tabel 10 di atas, maka responden yang memberikan pernyataan tentang Kegunaan (Usability) diperoleh skor rata-rata 5,03, responden yang memberikan pernyataan tentang Kualitas Informasi (Information Quality) diperoleh skor rata-rata 5,12, responden yang memberikan pernyataan tentang Kualitas Interaksi Pelayanan (Service Interaction Quality) diperoleh skor rata-rata 5,02 dan responden yang memberikan pernyataan tentang Keseluruhan (Overall) diperoleh skor rata-rata 5,11.

\section{Pembahasan}

Berdasarkan hasil skor rata-rata dari keempat variabel tersebut, ternyata skor rata-rata yang paling tinggi adalah Kualitas Informasi (Information Quality) yaitu 5,12 dan skor rata-ratayang paling rendah adalah Kualitas Interaksi Pelayanan (Service Interaction Quality) yaitu 5,02.Pada tabel 12 terlihat bahwa Kegunaan (Usability), Kualitas Informasi (Information Quality), Kualitas Interaksi Pelayanan (Service Interaction Quality) dan Keseluruhan (Overall) menghasilkan skor rata-rata 5,07. Dapat dikatakan bahwa seluruh dimensi kualitas website masih berada pada level 5 dari 6 level, artinya masih terdapat dimensi yang berpeluang untuk ditingkatkan untuk mencapai level 6 yaitu skor di atas 5,16 .

Apabila melihat tabel rentang skala ternyata bahwa variabel-variabel Website BPSDM Provinsi DKI Jakarta termasuk pada range 4,33 - 5,16, sehingga Kegunaan (Usability), Kualitas Informasi (Information Quality), Kualitas Interaksi Pelayanan (Service Interaction Quality) dan Keseluruhan (Overall) pada website BPSDM Provinsi DKI Jakarta sudah berkualitas. Namun demikian kualitas website BPSDM Provinsi DKI Jakarta masih dapat ditingkatkan pada level 6 dengan range 5,17-6,0 tentunya dengan mengevaluasi indikator-indikator pada dimensi-dimensi yang masih belum maksimal untuk ditingkatkan mencapai level 6.

\section{KESIMPULAN}

Berdasarkan hasil penelitian dan pembahasan di atas dapat disimpulkan bahwa Website BPSDM Provinsi DKI Jakarta telah memenuhi kualifikasi berkualitas berdasarkan dimensi kegunaan (Usability), kualitas informasi (Information Quality), dan kualitas interaksi pelayanan (Service Interaction Quality), maupun secara keseluruhan (Overall).

Hasil penelitian ini masih terbatas pada dimensi website berdasarkan metode WebQual 4.0 dan belum memberikan gambaran tentang kualitas pelayanan yang dapat dikaitkan dengan kepuasan pengguna. Oleh karena itu masih sangat terbuka untuk dilakukan kajian atau penelitian dengan menggunakan metode lainnya dan dengan dimensi yang berbeda, selain itu juga kajian kualitas pelayanan dengan pengukuran tingkat kepuasan pengguna. 


\section{DAFTAR PUSTAKA}

Abbas, W. (2013). Analisa Kepuasan Mahasiswa Terhadap Website Universitas Negeri Yogyakarta (UNY). Prosiding SNST Fakultas Teknik, 1.

Ariani, D. W. (2004). Pendekatan Kualitas Statistik, Pendekatan Kuantitatif dalam Manajemen Kualitas. Yogyakarta: Andi.

Arikunto, S. (2010). Metode Peneltian. Jakarta: Rineka Cipta.

Barnes, S. J, \& Vidgen, R. T. (2000). WebQual : An Exploration of Web-Site Quality. Proceedings of the Eighth European Conference on Information System, Vienna, July.

BKD DKI Jakarta. (2020). Rekapitulasi Jumlah Pegawai Negeri Sipil Pemerintah Provinsi DKI Jakarta Tahun 2020. Badan Kepegawaian Daerah Provinsi DKI Jakarta. https://bkddki.jakarta.go.id/statistik

Budi, S., \& Tyastianti, D. (2019). Manajemen Mutu. Lan: Vol.

Chomeya, R. (2010). Quality of Psychology Test Between Likert Scale 5 and 6 Points. Journal of Social Sciences.

Chutimaskul, W., Funilkul, S., \& Chongsuphajaisiddhi, V. (2008). The quality framework of egovernment development. Proceedings of the 2nd International Conference on Theory and Practice of Electronic Governance, 105-109.

Diana. (2014). Website e-government. Jurnal Informatika, 14(2), 202-212.

Medyawati, H., \& Dayanti, A. S. (2016). Pengaruh Ukuran Perusahaan terhadap Manajemen Laba: Analisis Data Panel. Jurnal Ilmiah Ekonomi Bisnis, 21(3), 142-152.

Puspitasari, A. N., Kumadji, S., \& Sunarti. (2013). Kepuasan Dan Loyalitas Pelanggan Pada Online Shop Studi pada Pelanggan Toko Sepatu Wanita www.iwearup.com. Jurnal Administrasi Bisnis, 5(2), 1-9.

Rohman, F., \& Kurniawan, D. (2017). Pengukuran Kualitas Website Badan Nasionalpenanggulangan Bencana Menggunakan. Jurnal Ilmu Pengertahuan Dan Teknologi Komputer, 3(1), 31-38.

Sanjaya, I. (2012). Pengukuran Kualitas Layanan Website Kementerian Kominfo dengan menggunakan Webqual 4.0. Jurnal Penelitian IPTEK-KOM, 14(1), 1-14.

Simarmata, J. (2010). Rekayasa web. Jakarta: Andi.

Singarimbun, M., \& Effendi, S. (2019). Metode penelitian survai. Jakarta: LP3ES.

Sugiyono. (2010). Metode penelitian kuantitatif dan kualitatif dan $R \& D$. Bandung: Alfabeta.

Sugiyono, P. D. (2013). Metode penelitian kuantitatif dan kualitatif dan R\&D [Quantitative and qualitative and $R \& D$ research methods]. Bandung: Alfabeta.

Sugiyono, P. D. (2017). Metode Penelitian Bisnis: Pendekatan Kuantitatif, Kualitatif, Kombinasi, dan $R \& D$. Bandung: Alfabeta.

Tarigan, J. (2008). User satisfaction using Webqual instrument: A research on stock exchange of Thailand (SET). Jurnal Akuntansi Dan Keuangan, 10(1), 24-47.

Yuhefizar, H. R., \& Hidayat, R. (2006). Cara Mudah Membangun Website Interaktif Menggunakan Content Management System Joomla. Jakarta: PT. Elex Media Komputindo. 